\title{
Estimating Consumer Preferences for Food, Using Time Series Data of Pakistan
}

\begin{abstract}
ABID A. BURKI
Consumer preferences for food and non-food items in Pakistan are frequently estimated by using data from the household surveys. However, structural change in consumer preferences, caused by changes in tastes, can be studied by using the annual time series data, a time series of cross sections, or the panel data. This paper uses Pakistan's annual time series disappearance data for eight food commodities from 1972 to 1991 to study consumer behaviour. The existence and the nature of structural change is tested by using both the generalised axiom of revealed preference (GARP) and the first-difference LA/AIDS model. It turns out that GARP tests are low-powered as tests of structural change on our data-set. However, the results from the LA/AIDS model show a shift in consumer demand from gram (split) to chicken after 1982. The data set satisfies symmetry and homogeneity. The estimates of price and income elasticities are also consistent with economic theory. The implications of these results for policy are also discussed.
\end{abstract}

\section{INTRODUCTION}

Research on estimating consumer preferences for food and non-food items in Pakistan has been growing. Over the past three decades, numerous studies have estimated household consumption patterns in Pakistan. They have used cross-section data from the Household Income and Expenditure Surveys (HIES), or household data from the Micro Nutrient Survey 1976. However, it is surprising that time series data on consumption and prices were never used in studies of consumer behaviour. Most studies tested for the validity of Engel's law using double-log specification on a single-equation basis. ${ }^{1}$ The inconsistent nature of the double logarithmic specification to consumers' utility maximisation is well-documented in Deaton and Muellbauer (1980a). The singleequation analysis in these studies is devoid of the advantages of a system approach as outlined in Barten (1977).

The system approach has been applied for estimating household consumer preferences using the Linear Expenditure System (LES) of Stone (1954), or the Extended Linear Expenditure System² (ELES) of Lluch (1973). For example, Mukhtar

Abid A. Burki is Assistant Professor, Department of Economics, Quaid-i-Azam University, Islamabad.

Author's Note: I would like to thank Gary Brester, Mushtaq Ahmad Khan, Dek Terrell, and an anonymous referee for many valuable comments on this paper.

${ }^{1}$ For a brief review and listing of these studies, see Burney and Khan (1991).

${ }^{2}$ The extended linear expenditure system variation allows endogenous determination of expenditures and thus makes it possible to measure the effect of relative prices on savings as well. 
(1985); Ahmad and Ludlow (1987) and Ahmad et al. (1988) estimated the household consumption behaviour by using the LES, while Ali (1985) applied the ELES to study the household consumption and savings behaviour in Pakistan. The advantage in using LES and ELES is that we can obtain estimates of subsistence quantities. However, the functional form assumed by the LES is quite restrictive. Moreover, its property of approximate proportionality between price and income elasticities is also not supported empirically or on theoretical grounds [Deaton and Muellbauer (1980a); King (1979, 1981)].

Alderman (1988) estimated consumer price and income elasticities by using the Almost Ideal Demand System (AIDS) of Deaton and Muellbauer (1980) on micro data of the HIES 1979. It is well-known that household surveys typically do not contain information on market prices that can be used to estimate price elasticities. ${ }^{3}$ Alderman's approach was innovative in that he used the respective household observations for the four quarterly rounds (in which the HIES data were collected) along with price movements for those quarters from published price series. In this way, he introduced regional variation in prices in addition to the time series variation. But, the definition of published price series and the commodity groupings used by Alderman were far from perfect. Moreover, he could not take into consideration the "quality effects" as suggested by Deaton (1988). There is the further concern that Alderman employed the linear approximate version of the AIDS model (LA/AIDS) but used the elasticity formulas of the AIDS. Green and Alston $(1990,1991)$ report that using AIDS elasticity formula in LA/AIDS parameters is not appropriate. They have shown that this is only appropriate when either the preferences are homothetic or the group price is constant. If the Green and Alston's observation is right, then Alderman elasticities may not be correct for his data-set. Moreover, the statistical significance of the Alderman elasticities is unknown, since he did not report the standard errors for his price and expenditure elasticities.

In another recent study Bouis (1992) has proposed a new technique to estimate income and price elasticities of food that is less data-demanding but uses a priori information regarding consumer behaviour. Even though there may be less data requirement in Bouis' method, it is unclear if his a priori information requirement is relatively more or less than an econometric model. ${ }^{4}$

Not surprisingly, the evidence on price and income elasticities from the existing studies on Pakistan is mixed due mainly to the variety of methods employed and the data used. This paper shows that food consumption patterns in Pakistan have changed during the past two decades. This change can partly be explained by the movement in relative prices of food and partly by the changes in income distribution and poverty. However,

${ }^{3}$ Deaton (1988), however, suggested a method to derive prices from household surveys after controlling for "quality effects" and for "measurement errors".

${ }^{4}$ Mukhtar (1992) has observed that this information requirement is much more than an econometric model. 
we cannot rule out the possibility that some non-price factors (such as the changes in tastes) may also have been instrumental in bringing about a structural change in consumer preferences. This phenomenon has received no attention whatsoever in previous consumer demand studies. The fact of the matter is that the existing studies on Pakistan could not estimate the changes in consumer preferences because they used the cross-section data.

The objective of this paper is to estimate consumer preferences for eight food commodities using Pakistan's annual time series disappearance data from 1972-73 to 1991-92. The paper tests for the existence of and the nature of structural change in these commodities by (a) examining the trends in per capita consumption of selected food items, (b) employing the non-parametric revealed preference axioms, and (c) estimating consumer preferences in the conventional framework of parametric demand analysis. More specifically, in the non-parametric framework, we test for the consistency of data with the utility maximisation principles using the generalised axiom of revealed preference (GARP). Moreover, employing the parametric demand analysis, the firstdifference form of the LA/AIDS model of Deaton and Muellbauer (1980) is used to estimate the parameters of food demand equations, and the price and expenditure elasticities. The inclusion of constants and dummies in the LA/AIDS model allow us to gain some important insights into the structural change in consumer preferences. The paper is organised as follows. The data development is discussed in Section II. Consumption patterns for food in Pakistan are discussed in Section III. Section IV presents non-parametric tests for structural change. The parametric demand model and results are given in Section V. Concluding comments are presented in Section VI.

\section{DATA}

Measurement errors in data in developing countries are generally expected to be large. However, there are no a priori grounds to believe that measurement errors in time series data would be larger than those of cross-section data. The representative nature of the HIES data of Pakistan has already been called in question by Kemal (1981) due to some apparent sampling problems. This is particularly true about the HIES 1979 on which most consumer demand studies were based.

No direct measures of annual consumption by commodity are available from Pakistan. Therefore, we developed disappearance data on quantities as a measure of retail consumption. The use of disappearance data as proxies for retail consumption is quite common in the United States, especially in meat demand studies. ${ }^{5}$ However, for unknown reasons, these data were never used for consumer demand analysis in Pakistan. We derived disappearance data from total wholesale production plus imports less exports multiplied by a scaler where necessary (to correct for various transformations). ${ }^{6}$

\footnotetext{
${ }^{5}$ See, for instance, Brester and Wohlgenant (1991) and Eales and Unnevehr (1988). For a discussion on measurement error in disappearance data and its method of correction, see Brester and Wohlgenant (1993). ${ }^{6}$ See Appendix Tables 1 and 2 for details.
} 
Small inventories of gram (split) and mung (split) are maintained by small traders, which we assumed constant for the entire period. ${ }^{7}$ Meat and milk are consumed fresh. Therefore, there is no question of inventories for these commodities. Rice is an export commodity, which cannot be stored for long periods. Hence, we assume that after local consumption the surplus is exported in the same year. Therefore, all inventories of rice are for export purposes only. ${ }^{8}$

We used annual data from 1972-73 to 1991-92 in the estimation. Eight food items, for which the required data was available, are picked. These items are beef, mutton, chicken, fish, rice, gram (split), mung (split), and milk (fresh). Retail prices and population are obtained from Pakistan Statistical Year Book [Government of Pakistan (1991)]. The consumer price index (CPI), implicit price deflator, and total personal consumption expenditures are from various issues of Economic Survey [Government of Pakistan (1997)]. Data on total production, imports, and exports of included quantities are also obtained from Economic Survey. The final data used in estimation are reported in Appendix Tables 1 and 2.

\section{CONSUMPTION PATTERNS FOR FOOD IN PAKISTAN}

Food consumption patterns in Pakistan have changed during the last two decades. In particular, consumption of meats has increased while the consumption of lentils (i.e., gram and mung) has steadily decreased. Figure 1 illustrates consumption patterns for four meats together with gram and mung, based on annual per capita consumption data (Appendix Table 1). Although the consumption of mutton and chicken has steadily increased since early 1970s, beef consumption increased only in mid-eighties after remaining constant in the earlier period. Fish consumption has also remained constant during this entire period. Per capita chicken consumption which doubled in the first seven years continued to grow even faster in the 1980s. The most interesting relationship, however, is the perfect substitution between beef and mutton all along the study period (Figure 1). In contrast, the cross-price effects between red meats (beef and mutton) and white meats (chicken and fish) are not that obvious. The consumption of gram registered a sharp decrease in the 1970s before following a fluctuating trend in the 1980s. Moreover, the consumption of mung shows a somewhat steady decline during the entire study period.

It should be emphasised that rice, milk, gram (split), and mung (split) are essential food commodities for lower-income groups in Pakistan. Beef, mutton, chicken, and fish are expensive substitutes for gram (split) and mung (split). Within the meat group, beef has a lower preference while mutton and chicken have always enjoyed

\footnotetext{
${ }^{7}$ Little food is consumed away-from-home in Pakistan, except in two big cities, i.e., Karachi and Lahore. Thus, the proportion of food consumed away from home in total consumption can be ignored.

${ }^{8}$ Rice Export Corporation (REC) is a subsidiary of the Government of Pakistan which has had a monopoly in rice export since 1974. The support price for rice is set by the Government on an annual basis. Rice is purchased from growers by the REC on pre-determined prices.
} 


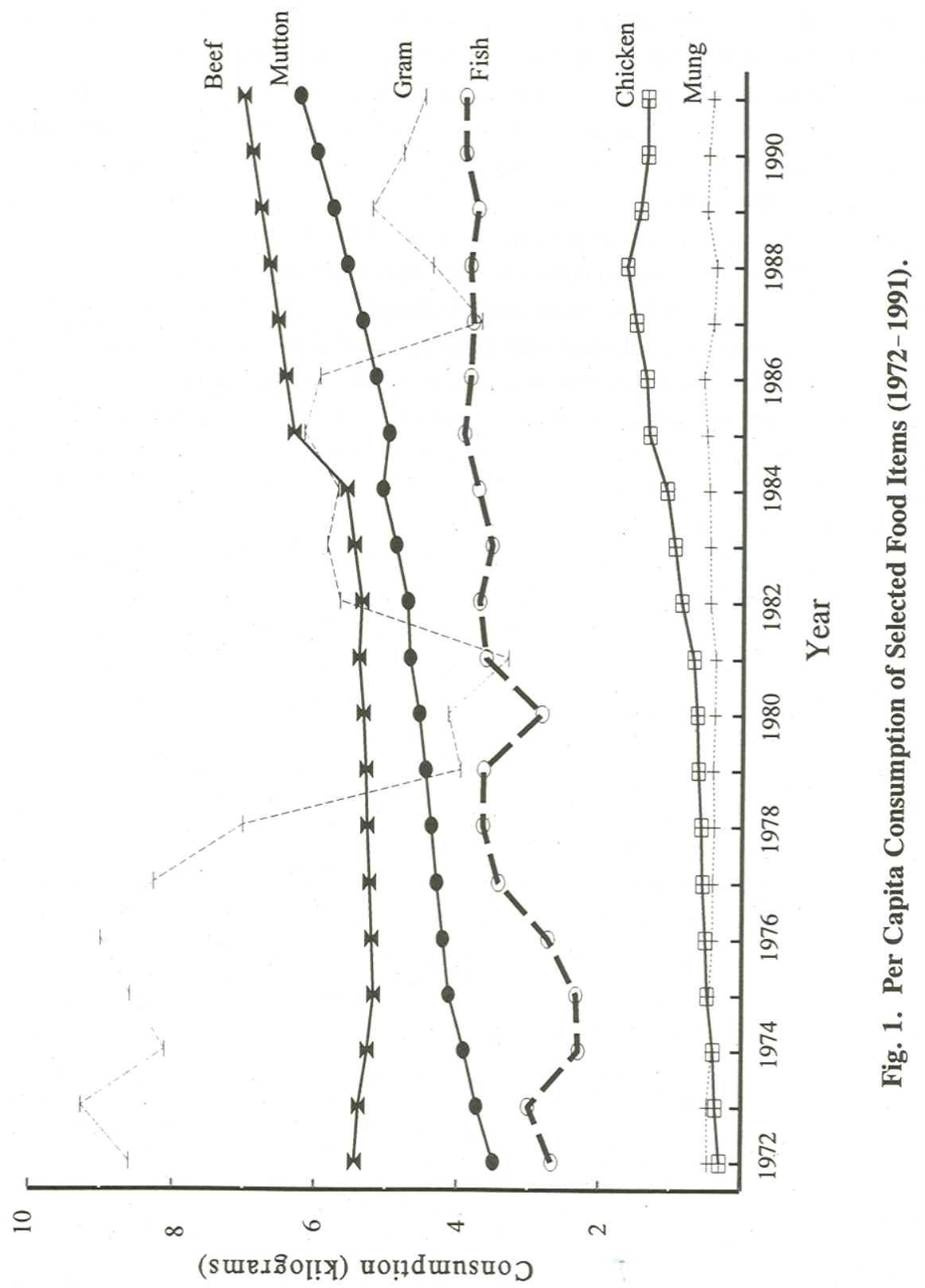


relatively higher preference ordering in consumer demand. This is indicated by the huge price differential between beef and mutton, and between beef and chicken. During our study period, the price of mutton was more than double the price of beef. Even though the prices of mutton and chicken were similar during the 1970s, the price of chicken declined in the 1980s. This is explained by increased production of chicken since 1980s due to government incentives. This has decreased the price of chicken relative to mutton and beef. ${ }^{9}$ Consumption of all meats and milk has increased although the relative prices of beef, mutton, fish, and milk have increased more than most other commodities (see Appendix Tables 1 and 2).

The observed changes in per capita consumption of food can partly be explained by decreased prices of chicken due to increased productivity, and partly by changes in the demand structure for food on account of changes in demographic factors, changes in economic well-being, and, most importantly, a change in consumer preferences due to changes in consumer tastes. Pakistan's economy has undergone changes in terms of income distribution and the incidence of poverty in recent years. More specifically, poverty has been reduced while income inequalities have increased during the last two decades. The urban and rural poverty that increased during the 1960s has consistently decreased in the 1970s and 1980s [Irfan and Amjad (1984)]. The primary cause for this decline is reported to be the huge inflow of remittances by Pakistani emigrants to Middle Eastern countries. The exodus of the Pakistani labour force to the booming Middle Eastern countries took place during the late 1970s and throughout the 1980s. The stock of migrant workers (mostly production workers) that was a few thousand in the mid-1970s increased to more than 1.8 million in 1985, which amounts to about 7 percent of the total labour force in Pakistan [Kazi (1988)]. ${ }^{10}$ The primary objective of migrant workers was to save money for a better and prosperous living for them and their families. ${ }^{11}$ This resulted in a huge inflow of remittances to the households of emigrant workers. ${ }^{12}$ As a result, the levels of real income for lower-income and lower-middleincome households increased in the late 1970s and throughout the 1980s. Non-migrating production and non-production workers benefited by the outflow indirectly through increased real wages due to shortages of skilled and unskilled workers in the domestic labour market. Such increases in real incomes are known to have drastically reduced the number of households falling below the poverty-line [Irfan and Amjad (1984)]. There

\footnotetext{
${ }^{9}$ Chicken prices that were only 12 percent lower than mutton prices in 1979 decreased sharply in the 1980s, widening this price differential to more than 39 percent in 1991. Similarly, sharp decreases in chicken prices narrowed the price differential between chicken and beef from 49 percent in 1979 to only 9 percent in 1991.

${ }^{10}$ The majority of these workers (42 percent) were unskilled. Professional workers like doctors, engineers, nurses, and accountants, etc., were only 1.7 percent of the total emigrants in 1977-85 [Kazi (1988)].

${ }^{11}$ Surveys conducted by the International Labour Organisation show that, on average, Pakistani migrants saved 23 percent of their monthly incomes [ILO/ARTEP (1987)].

${ }^{12}$ Remittances increased from $\$ 932.9$ million in 1977-78 to a peak of \$2402.9 million in 1982-83 and decreased to $\$ 2021.8$ million in 1985-86. These remittances were approximately equal to the total export earnings in 1982-83, and were about 10 percent of Pakistan's GNP in the same year [Kazi (1988)].
} 
remains, however, the possibility that some non-price factors may also have contributed to this change. For instance, a gradual change in consumer preferences could have taken place due to changes in tastes perhaps as a result of cultural factors through the returning migrant labour force from the Middle East, or for other unknown reasons. If this hypothesis is correct, then these evolutionary changes may have produced new consumption patterns that may explain the observed growth in the demand for expensive food items.

\section{NON-PARAMETRIC TESTS FOR STRUCTURAL CHANGE}

The non-parametric demand analysis is based on the revealed preference theory popularised among others by Koo (1963, 1971); Afriat (1967) and Varian $(1982,1983)$. This approach uses data on observed prices and quantities and tests its consistency with utility maximisation using the revealed preference axioms. ${ }^{13}$ These axioms are increasingly used in the consumer demand analysis as a complement to the parametric analysis, especially to pre-test the consistency of data sets with the theory.

\section{(a) Revealed Preference Axioms}

To describe these axioms, suppose we have two bundles $x$ and $y$. If $x$ is chosen over $y$ then we say $x$ is revealed preferred to $y$ and denote it as $x R y$. The weak axiom of revealed preference (WARP) states that if $x R y$ and $x \neq y$, then $y$ cannot be revealed preferred to $x$ [Varian $(1982,1992)]$. If any such bundle as $y$ is also revealed as preferred to $x$, then it will be a violation of WARP. Such a violation can only occur when the indifference curves shift.

To generalise WARP for $N$ goods, let $P$ be a $T \times N$ matrix consisting of observed price vectors of length $N$, and $Q$ be a $T \times N$ matrix consisting of observed quantity vectors. Each element $\Phi_{i j}$ of the matrix $\Phi=P Q^{\prime}$ expresses cost of purchasing time $j$ bundles at prices in time-periods denoted by $i .^{14}$ For the case of three bundles and three time-periods, the elements of this matrix are expressed as

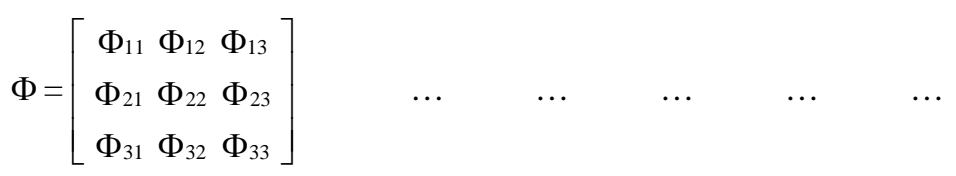

where the elements in each row represent the cost of purchasing bundles at time-periods 1 to 3 . For example, $\Phi_{11}$ depicts the actual expenditures on bundle " 1 " at time " 1 " prices

\footnotetext{
${ }^{13}$ For recent applications of this approach, see, for instance, Swofford and Whitney (1987); Chalfant and Alston (1988); Chavas and Cox (1990); Jensen and Bevins (1991); Alston and Chalfant $(1991,1992)$ and Fleissig et al. (1995).

${ }^{14}$ For more details, see Chalfant and Alston (1988).
} 
while $\Phi_{12}$ is the expenditure on bundle " 2 " consumed in time " 2 " at time " 1 " prices. If $\Phi_{11}>\Phi_{12}$, then bundle " 1 " is revealed as preferred to bundle " 2 ". However, if bundle "1" was affordable at time "2" prices, such that $\Phi_{22}>\Phi_{21}$, then it is considered as a violation of the WARP. The consistency of data with WARP is established only when there is no violation of WARP. This is, however, a necessary but not sufficient condition for utility maximisation. The strong axiom of revealed preference (SARP) relates to the transitivity property of the utility function. Therefore, to search for intransitivity in the observed data, the consistency of data with SARP is recommended.

The generalised axiom of revealed preference (GARP) is a test which generalises other tests in the family of revealed preference. WARP and SARP are standard tests, which require that for each budget there be a unique bundle demanded. In contrast, testing for GARP would allow multiple solutions to the consumer's optimisation [Varian (1992)]. In other words, GARP also allows "flat spots" in the indifference curves. The consistency of data with GARP implies WARP; however, the reverse is not true. Likewise, even when we find no violations of WARP, it is necessary to check for GARP or SARP. Therefore, GARP is the necessary and sufficient condition for the consistency of data with utility maximisation [Varian (1982)].

\section{(b) Testing for Structural Change}

If observed consumption patterns are stable and thus are explained by changes in relative prices and expenditures, then GARP is expected to hold. ${ }^{15}$ However, violations of revealed preference in testing GARP imply that factors other than prices and expenditures, e.g., changes in tastes, and demographic factors, etc., affect the observed consumption pattern. Such preference ordering is considered as evidence in favour of a structural change. Here it should be stressed that in the data sets which show a strong trend in expenditures, or where the growth in income is large relative to variations in prices, GARP violations are highly unlikely to be found [Chalfant and Alston (1988)]. In other words, the power of non-parametric tests is very low in such situations. ${ }^{16}$

We used NONPAR, a software developed by Hal Varian, which performs GARP and other non-parametric tests. The time series of prices and quantities from 1972-73 to 1991-92 for eight food commodities was tested for consistency with GARP. Our test produced zero violations of GARP. Considering the observed income growth in Pakistan during the last two decades, this failure to reject GARP does not necessarily mean that structural change does not exist. ${ }^{17}$ The issue here is the power of the GARP test itself.

${ }^{15}$ Other studies that have used GARP to test for structural change include Chalfant and Alston (1988); Thurman (1987); Alston and Chalfant (1991, 1992) and Wellman (1992).

${ }^{16}$ The power of the non-parametric tests is discussed in Chalfant and Alston (1988) and Alston and Chalfant (1991, 1992).

${ }^{17}$ For example, Thurman (1987) notes that if data do not support structural change by the nonparametric tests, this is not an evidence against structural change. 
There has been some progress to deal with this issue. For instance, Chalfant and Alston (1988) suggested that this problem can be solved by adjusting the data for income growth using the expenditure elasticities. This transformation of data increases the comparable data points in GARP tests. Following Chalfant and Alston (1988) we first used unitary income elasticity for all the eight commodities to transform the data set for increasing incomes and expenditures. Conducting GARP consistency test once again on the transformed data produced 297 violations of stable preferences. It is interesting to note that the adjusted per capita consumption data find between 4 and 14 observations of negative consumption levels for all goods except milk. The negative values in adjusted data apparently suggest that our transformation based on unitary elasticity may not be accurate. ${ }^{18}$ We tried several other transformations including the ones based on prior beliefs about expenditure elasticities for individual commodities from previous studies. Nevertheless, in neither case did we obtain zero violations of GARP.

It appears from these results that over the study period non-price and nonexpenditure factors may have a significant impact on consumer behaviour in Pakistan. If so, this result can be considered as reflecting a structural change in consumption patterns over the observed time series. However, the fact remains that the non-parametric test results do not provide unequivocal support in favour of structural change. As it turns out, re-testing GARP on adjusted time series is very sensitive to the chosen elasticities for adjustment. Prior beliefs about expenditure elasticities may be helpful in making such adjustments in some applications, but we could not succeed in discovering such an adjustment procedure that "rationalises” the data. How much confidence we could place on these results depends in part on the accuracy of the data adjustment procedure and the assumed elasticities. To investigate this issue further, we have modelled structural change in the following parametric demand model.

\section{PARAMETRIC DEMAND ANALYSIS}

\section{(a) Model Specification}

The AIDS model represents a complete demand system, which is flexible, does not require additive preferences, satisfies the axioms of choice, and has the property of consistent aggregation from micro to the market level while allowing non-linear Engel curves. ${ }^{19}$ The homogeneity and symmetry restrictions can easily be tested/imposed since

${ }^{18}$ Alston and Chalfant (1992) also pointed out that re-testing GARP on adjusted data is very sensitive to the chosen elasticities for adjustment.

${ }^{19}$ Alston and Chalfant (1993) have developed a specification test for the appropriateness of the Rotterdam and LA/AIDS models against each other. They argued that in some applications the choice between the two does matter. We applied their compound model as a test of the LA/AIDS and the Rotterdam specifications on our data-set but the results were ambiguous and do not provide a basis to determine which model specification is preferred. With the Rotterdam model as the null hypothesis, the value of $\lambda_{1}$ was 0.06 with a standard error of 0.0137 . Since the $t$-value was 4.247 , we reject the null that the Rotterdam model is the correct specification. Using the LA/AIDS specification the test of hypothesis that $\lambda_{2}$ equals zero was also rejected. Therefore, this specification test is of no use in this application. 
these depend on estimated parameters.

In budget share form, the derived equations from the AIDS model are

$$
w_{i}=\alpha_{i} \sum_{j} \gamma_{i j} \ln p_{j}+\beta_{i} \ln \left(\frac{X}{P}\right), \quad \ldots \quad \ldots \quad \ldots
$$

where $P$ is a price index defined by

$$
\ln P=\alpha_{0}+\sum_{k} \alpha_{k} \ln p_{k}+\frac{1}{2} \sum_{j} \sum_{k} \gamma_{k j} \ln p_{k} \ln p_{j} \forall i, \quad \ldots \quad \ldots
$$

and $w_{i}$ is the budget share on ith good, $X$ is the total expenditure on all commodities in the system, $P_{j}$ 's are prices, and $\ln P$ is a price index. In the LA/AIDS version, $\ln P$ in (2) is replaced by Stone's geometric price index written as

$$
\ln P^{*}=\sum_{k} w_{k} \ln p_{k} \cdot \quad \ldots \quad \ldots \quad \ldots \quad \ldots \quad \ldots
$$

We examine structural change by focusing on gradual exogenous shifts in the demand curves and a one-time shift in demand after the emigration of Pakistani workers started. ${ }^{20}$ We, however, do not focus on the changes in slope parameters due to limited degrees of freedom. To examine structural change the model will be estimated in firstdifference form with an intercept term and a one-period intercept dummy variable $D$ that is 1 for the years when structural change is expected, and 0 otherwise. Since the exact timing of structural change is unknown, we will explore all the possibilities since outmigration significantly set in, i.e., 1978-79. Thus the estimated model is

$$
\Delta w_{i}=\alpha_{i}+\theta_{i} D+\sum_{j} \gamma_{i j} \Delta \ln p_{j}+\beta_{i} \Delta \ln \left(\frac{X}{P^{*}}\right), \quad \ldots \quad \ldots
$$

where $\Delta$ denotes the first-difference operator in the model. In this form, a non-zero intercept implies a gradual exogenous shift in demand and a non-zero significant oneperiod dummy indicates a shift in demand in the respective year.

The standard restrictions of demand theory (i.e., adding up, homogeneity, and symmetry) can be imposed in terms of model parameters as

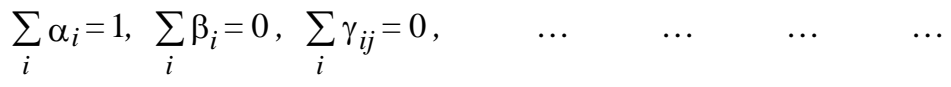

$$
\begin{aligned}
& \begin{array}{lllllll}
\sum_{i} \gamma_{i j}=0, & \cdots & \ldots & \ldots & \ldots & \ldots & \ldots
\end{array} \\
& \begin{array}{lllllll}
\gamma_{i j}=\gamma_{j i}, & \ldots & \ldots & \ldots & \ldots & \ldots & \ldots
\end{array}
\end{aligned}
$$

${ }^{20}$ Similar techniques were used by Eales and Unnevehr $(1988,1993)$ to test for structural change in the demand for meats in the U.S. 
where (6.1) is the adding up condition, (6.2) depicts zero homogeneity in prices, and (6.3) is the Slutsky symmetry condition.

We shall use the price and expenditure elasticity formulas suggested by Green and Alston $(1990,1991)$. For uncompensated price elasticities, the formula expressed in matrix notation is

$$
E=[B C+1]^{-1}[A+1]-1 \quad \ldots \quad \ldots \quad \ldots \quad \ldots \quad \ldots
$$

The typical elements in $A$ (an $n \times n$ matrix) are $\alpha_{i j}=-\delta_{i j}+\left(\gamma_{i j} / w_{i}\right)-\beta_{i}\left(w_{j} / w_{i}\right)$ where $\delta_{i j}$ is the Kronecker delta $\left(\delta_{i j}=1\right.$ for $i=j ; \delta_{i j}=0$ for $i \neq j$ ); $B$ (an $n \times 1$ vector) consists of $b_{i}=\left(\beta_{i} / w_{i}\right) ; C($ a $1 \times n$ vector $)$ has $c_{j}=w_{j} \ln P_{j}$; and $I$ is an identity matrix. The income elasticities will be measured by $N$ (an $n \times 1$ matrix) as

$$
N=(I+B C)^{-1} B+i, \quad \ldots \quad \ldots \quad \ldots \quad \ldots \quad \ldots
$$

where $N$ expresses an $n$-vector of expenditure elasticities, and $i$ is an $n$ unit vector.

Compensated elasticities will be estimated as

$$
\begin{array}{lllllll}
E^{*}=E+N W^{\prime}, & \ldots & \ldots & \ldots & \ldots & \ldots & \ldots
\end{array}
$$

where $E$ is the matrix of uncompensated price elasticities, $N$ is the matrix of income elasticities, and $W^{\prime}$ is an $n$-vector of budget shares.

\section{(b) Empirical Results}

The system of equations for nine commodities (eight food commodities and one other) was estimated using the first-difference LA/AIDS model in (5). The test of the symmetry (with homogeneity imposed) could not be rejected at the 0.05 level, ${ }^{21}$ so these restrictions were imposed. Curvature conditions were not met, since the substitution matrix was not negative semi-definite. ${ }^{22}$ The model was estimated using iterative seemingly unrelated regressions procedure. Because of the adding up constraint, only eight out of the nine equations were independent. Therefore, we deleted the equation for other goods to ensure non-singularity of the error covariance matrix. The estimates are invariant to the deleted equation. The parameters of the deleted equation were recovered using the restrictions of adding up, homogeneity, and symmetry. Due to the use of restrictions in (6), the model has 60 free parameters. Altogether, we have 152 effective observations to estimate these parameters.

\footnotetext{
${ }^{21}$ The $\chi^{2}$ test statistic for the likelihood ratio test was 38.79 , which was less than the critical value of 41.34 at 28 degrees of freedom at the 0.05 level.

${ }^{22}$ Three of the nine eigenvalues were positive.
} 
Table 1 shows that the intercept terms for beef, mutton, chicken, fish, and others are statistically significant and positive. This indicates an exogenous growth in the demand for these commodities, independently of the movement in prices and income. The intercept for gram (split) was also statistically significant but with a negative sign. It implies that there has been a rapid exogenous decline over time in the share of gram. The exact time for the expected structural change was not known; therefore, we varied the break-point for one period dummy from 1978-79 to 1991-92. We found that these dummies were statistically significant only for the period 1982-83 through 1991-92 for chicken and gram (split). Our results show that the shares of all other foods have remained unchanged between 1972-73 to 1991-92. The trend growth for chicken has a positive sign as expected. The positive and significant dummy for chicken suggests that the exogenous growth in the share of chicken demand was faster after 1982-83 than before it. Dummy and constant for gram are significant. Their coefficients depict that the total share of gram increased before 1982 and declined afterwards.

The observed increase in chicken demand and a decrease in the demand for gram after 1982-83 can be explained by changes in taste. Since chicken and gram are substitutes, these results are plausible and make sense. It appears that the lower-income households have changed their preferences and have substituted chicken for gram (split). The demands for other meats have also grown in the same period.

The compensated elasticities ${ }^{23}$ are reported in Table 2 along with their standard errors. ${ }^{24}$ All the own price elasticities, except for rice, are reasonable in signs and magnitude. However, the own price elasticities for chicken, rice, and gram are not statistically different from zero. The cross-price substitution effects between beef, mutton, and chicken are fairly large and significant in most cases. Only the complementary relation between mutton and chicken and between mutton and fish are hard to explain. It may be that the demand relationship between these categories changed from substitution to complement because of the structural change. Besides, the relation between meats, gram (split), and mung (split) have the expected cross-price substitution effects. The substitution and complementary relation of rice with all other commodities is also as expected. Moreover, the complementary relation of milk (fresh) with all other commodities is plausible.

The expenditure elasticities for all commodities, except for chicken and gram, are positive and less than one, which means that they are necessary goods. The expenditure elasticity for chicken is more than one, which is quite reasonable, given the nature of consumer preferences for different meats in Pakistan. The expenditure elasticities for

\footnotetext{
${ }^{23}$ For highly disaggregated commodities, as ours, the expenditure shares are also very small. Therefore, uncompensated and compensated elasticities are approximately the same.

${ }^{24}$ The standard errors and $t$-values were obtained by using the ANALYZ command in TSP [Hall (1996)]. The method employed in this command is to take Taylor series approximation of the non-linear function around the estimated parameters and to use the formulas for linear functions of random variables to estimate the variances and covariances.
} 
Table 1

Parameter Estimates for LA/AIDS Model

\begin{tabular}{|c|c|c|c|c|c|c|c|c|c|c|c|c|}
\hline Equation & Constant & Expenditure & Dummy & Beef & Mutton & Chicken & Fish & Rice & $\begin{array}{c}\text { Gram } \\
\text { (Split) }\end{array}$ & $\begin{array}{l}\text { Mung } \\
\text { (Split) }\end{array}$ & $\begin{array}{c}\text { Milk } \\
\text { (Fresh) }\end{array}$ & Others \\
\hline Beef & $\begin{array}{c}0.017^{*} \\
(0.009)\end{array}$ & $\begin{array}{c}-0.13^{* *} \\
(0.09)\end{array}$ & $\begin{array}{c}-0.008 \\
(0.02)\end{array}$ & $\begin{array}{c}0.11^{*} \\
(0.02)\end{array}$ & $\begin{array}{c}0.061^{*} \\
(0.035)\end{array}$ & $\begin{array}{c}0.05^{*} \\
(0.02)\end{array}$ & $\begin{array}{c}-0.03^{* *} \\
(0.02)\end{array}$ & $\begin{array}{c}0.04 \\
(0.043)\end{array}$ & $\begin{array}{c}0.004 \\
(0.01)\end{array}$ & $\begin{array}{c}0.003 \\
(0.004)\end{array}$ & $\begin{array}{c}-0.01 \\
(0.08)\end{array}$ & $\begin{array}{c}-0.14 \\
(0.13)\end{array}$ \\
\hline Mutton & $\begin{array}{c}0.04^{*} \\
(0.016)\end{array}$ & $\begin{array}{c}-0.07 \\
(0.15)\end{array}$ & $\begin{array}{c}0.02 \\
(0.04)\end{array}$ & $\begin{array}{c}0.061^{*} \\
(0.035)\end{array}$ & $\begin{array}{c}0.34^{*} \\
(0.09)\end{array}$ & $\begin{array}{c}-0.11^{*} \\
(0.03)\end{array}$ & $\begin{array}{c}-0.27^{*} \\
(0.05)\end{array}$ & $\begin{array}{c}-0.09 \\
(0.08)\end{array}$ & $\begin{array}{c}0.02 \\
(0.021)\end{array}$ & $\begin{array}{c}-0.004 \\
(0.007)\end{array}$ & $\begin{array}{l}-0.21^{* *} \\
(0.14)\end{array}$ & $\begin{array}{c}0.25 \\
(0.24)\end{array}$ \\
\hline Chicken & $\begin{array}{c}0.009 * \\
(0.004)\end{array}$ & $\begin{array}{c}0.01 \\
(0.04)\end{array}$ & $\begin{array}{c}0.016^{*} \\
(0.009)\end{array}$ & $\begin{array}{c}0.05 \\
(0.02)\end{array}$ & $\begin{array}{c}-0.11^{*} \\
(0.03)\end{array}$ & $\begin{array}{c}0.06^{*} \\
(0.03)\end{array}$ & $\begin{array}{c}0.03 \\
(0.03)\end{array}$ & $\begin{array}{l}-0.04^{* *} \\
(0.03)\end{array}$ & $\begin{array}{c}0.016^{*} \\
(0.008)\end{array}$ & $\begin{array}{l}0.007^{* *} \\
(0.005)\end{array}$ & $\begin{array}{c}-0.13^{*} \\
(0.04)\end{array}$ & $\begin{array}{l}0.109^{* *} \\
(0.067)\end{array}$ \\
\hline Fish & $\begin{array}{c}0.02 * \\
(0.009)\end{array}$ & $\begin{array}{c}-0.14 * * \\
(0.084)\end{array}$ & $\begin{array}{c}0.008 \\
(0.024)\end{array}$ & $\begin{array}{c}-0.03^{*} \\
(0.02)\end{array}$ & $\begin{array}{c}-0.27^{*} \\
(0.05)\end{array}$ & $\begin{array}{c}0.03 \\
(0.03)\end{array}$ & $\begin{array}{c}0.12 * \\
(0.05)\end{array}$ & $\begin{array}{c}0.11 * \\
(0.05)\end{array}$ & $\begin{array}{l}-0.01 \\
(0.013)\end{array}$ & $\begin{array}{c}0.01^{*} \\
(0.006)\end{array}$ & $\begin{array}{l}-0.19 * \\
(0.008)\end{array}$ & $\begin{array}{c}0.23^{* *} \\
(0.145)\end{array}$ \\
\hline Rice & $\begin{array}{c}-0.02 \\
(0.03)\end{array}$ & $\begin{array}{c}-0.30 \\
(0.25)\end{array}$ & $\begin{array}{c}0.009 \\
(0.07)\end{array}$ & $\begin{array}{c}0.04 \\
(0.01)\end{array}$ & $\begin{array}{l}-0.09 \\
(0.08)\end{array}$ & $\begin{array}{c}-0.04 \\
(0.03)\end{array}$ & $\begin{array}{c}0.11 \\
(0.05)\end{array}$ & $\begin{array}{l}0.34^{* *} \\
(0.21)\end{array}$ & $\begin{array}{l}0.06^{* *} \\
(0.04)\end{array}$ & $\begin{array}{c}0.003 \\
(0.006)\end{array}$ & $\begin{array}{c}0.019 \\
(0.211)\end{array}$ & $\begin{array}{c}-0.44 \\
(0.36)\end{array}$ \\
\hline Gram (Split) & $\begin{array}{c}-0.017 * \\
(0.007)\end{array}$ & $\begin{array}{l}-0.19 \\
(0.06)\end{array}$ & $\begin{array}{c}0.08^{*} \\
(0.017)\end{array}$ & $\begin{array}{c}0.004 \\
(0.01)\end{array}$ & $\begin{array}{c}0.02 \\
(0.021)\end{array}$ & $\begin{array}{c}0.016^{*} \\
(0.008)\end{array}$ & $\begin{array}{l}-0.01 \\
(0.013)\end{array}$ & $\begin{array}{c}0.06 \\
(0.04)\end{array}$ & $\begin{array}{c}0.09 * \\
(0.01)\end{array}$ & $\begin{array}{c}-0.002 \\
(0.001)\end{array}$ & $\begin{array}{c}-0.008 \\
(0.05)\end{array}$ & $\begin{array}{c}-0.17^{*} \\
(0.089)\end{array}$ \\
\hline Mung (Split) & $\begin{array}{l}-0.0006 \\
(0.0007)\end{array}$ & $\begin{array}{l}-0.01^{*} \\
(0.006)\end{array}$ & $\begin{array}{c}0.001 \\
(0.002)\end{array}$ & $\begin{array}{c}0.003 \\
(0.004)\end{array}$ & $\begin{array}{l}-0.004 \\
(0.007)\end{array}$ & $\begin{array}{c}0.007 \\
(0.005)\end{array}$ & $\begin{array}{c}0.01^{*} \\
(0.006)\end{array}$ & $\begin{array}{c}0.003 \\
(0.006)\end{array}$ & $\begin{array}{l}-0.002 \\
(0.001)\end{array}$ & $\begin{array}{c}0.01^{*} \\
(0.002)\end{array}$ & $\begin{array}{l}-0.009 \\
(0.007)\end{array}$ & $\begin{array}{l}-0.02 * \\
(0.012)\end{array}$ \\
\hline Milk (Fresh) & $\begin{array}{l}0.104 * \\
(0.05)\end{array}$ & $\begin{array}{l}-1.20^{*} \\
(0.445)\end{array}$ & $\begin{array}{c}-0.05 \\
(0.13)\end{array}$ & $\begin{array}{l}-0.01 \\
(0.08)\end{array}$ & $\begin{array}{l}-0.21 \\
(0.14)\end{array}$ & $\begin{array}{c}-0.13^{*} \\
(0.04)\end{array}$ & $\begin{array}{l}-0.19 * \\
(0.008)\end{array}$ & $\begin{array}{c}0.019 \\
(0.211)\end{array}$ & $\begin{array}{l}-0.008 \\
(0.05)\end{array}$ & $\begin{array}{l}-0.009 \\
(0.007)\end{array}$ & $\begin{array}{c}1.20^{*} \\
(0.44)\end{array}$ & $\begin{array}{c}-0.601 \\
(0.68)\end{array}$ \\
\hline Others & $\begin{array}{c}-0.16^{*} \\
(0.08)\end{array}$ & $\begin{array}{c}2.02 * \\
(0.75)\end{array}$ & $\begin{array}{c}-0.09 \\
(0.17)\end{array}$ & $\begin{array}{c}-0.14 \\
(0.13)\end{array}$ & $\begin{array}{c}0.25 \\
(0.24)\end{array}$ & $\begin{array}{c}0.109 \\
(0.067)\end{array}$ & $\begin{array}{c}0.23 \\
(0.145)\end{array}$ & $\begin{array}{c}-0.44 \\
(0.36)\end{array}$ & $\begin{array}{c}-0.17^{*} \\
(0.089)\end{array}$ & $\begin{array}{c}-0.02^{*} \\
(0.012)\end{array}$ & $\begin{array}{c}-0.601 \\
(0.68)\end{array}$ & $\begin{array}{c}0.79 \\
(1.23)\end{array}$ \\
\hline
\end{tabular}

Note: All coefficients are multiplied by 10 for ease of presentation. Figures in parentheses are asymptotic standard errors.

* Indicates significance at 0.05 percent level.

** Indicate significance at 0.10 percent level. 
Table 2

Estimated Compensated Elasticities at the Sample Mean

\begin{tabular}{|c|c|c|c|c|c|c|c|c|c|c|c|}
\hline \multirow[b]{2}{*}{ Equation } & \multirow[b]{2}{*}{$\begin{array}{l}\text { Mean } \\
\text { Share }\end{array}$} & \multirow{2}{*}{$\begin{array}{c}\text { Expenditure } \\
\text { Elasticity } \\
\text { of }\end{array}$} & \multicolumn{9}{|c|}{ Price Elasticity of } \\
\hline & & & Beef & Mutton & Chicken & Fish & Rice & $\begin{array}{c}\text { Gram } \\
\text { (Split) }\end{array}$ & $\begin{array}{l}\text { Mung } \\
\text { (Split) }\end{array}$ & $\begin{array}{c}\text { Milk } \\
\text { (Fresh) }\end{array}$ & Others \\
\hline Beef & 0.028 & $\begin{array}{c}0.53^{*} \\
(0.305)\end{array}$ & $\begin{array}{c}-0.58^{*} \\
(0.077)\end{array}$ & $\begin{array}{c}0.24^{*} \\
(0.13)\end{array}$ & $\begin{array}{c}0.20^{*} \\
(0.06)\end{array}$ & $\begin{array}{c}-0.097 \\
(0.08)\end{array}$ & $\begin{array}{c}0.16 \\
(0.15)\end{array}$ & $\begin{array}{c}0.02 \\
(0.013)\end{array}$ & $\begin{array}{c}0.01 \\
(0.01)\end{array}$ & $\begin{array}{l}-0.24 \\
(0.316)\end{array}$ & $\begin{array}{l}-0.24 \\
(0.46)\end{array}$ \\
\hline Mutton & 0.049 & $\begin{array}{c}0.86^{*} \\
(0.299)\end{array}$ & $\begin{array}{c}0.13^{*} \\
(0.073)\end{array}$ & $\begin{array}{c}-0.29 * \\
(0.161)\end{array}$ & $\begin{array}{c}-0.22^{*} \\
(0.07)\end{array}$ & $\begin{array}{c}-0.55^{*} \\
(0.11)\end{array}$ & $\begin{array}{l}-0.17 \\
(0.17)\end{array}$ & $\begin{array}{c}0.04 \\
(0.042)\end{array}$ & $\begin{array}{l}-0.07 \\
(0.014)\end{array}$ & $\begin{array}{l}-0.39 \\
(0.307)\end{array}$ & $\begin{array}{c}0.59 \\
(0.47)\end{array}$ \\
\hline Chicken & 0.041 & $\begin{array}{c}1.15^{*} \\
(0.45)\end{array}$ & $\begin{array}{c}0.69 * \\
(0.192)\end{array}$ & $\begin{array}{c}-1.37 * \\
(0.43)\end{array}$ & $\begin{array}{l}-0.22 \\
(0.362)\end{array}$ & $\begin{array}{c}0.37 \\
(0.38)\end{array}$ & $\begin{array}{c}-0.56^{* *} \\
(0.41)\end{array}$ & $\begin{array}{l}0.201 * \\
(0.099)\end{array}$ & $\begin{array}{l}0.092 * * \\
(0.057)\end{array}$ & $\begin{array}{c}-1.63^{*} \\
(0.51)\end{array}$ & $\begin{array}{l}1.28 * \\
(0.74)\end{array}$ \\
\hline Fish & 0.026 & $\begin{array}{c}0.46 * * \\
(0.32)\end{array}$ & $\begin{array}{c}-0.10 \\
(0.09)\end{array}$ & $\begin{array}{c}-1.02 * \\
(0.21)\end{array}$ & $\begin{array}{c}0.12 \\
(0.12)\end{array}$ & $\begin{array}{c}-0.53^{*} \\
(0.19)\end{array}$ & $\begin{array}{c}0.45^{*} \\
(0.21)\end{array}$ & $\begin{array}{l}-0.04 \\
(0.05)\end{array}$ & $\begin{array}{c}0.05^{*} \\
(0.02)\end{array}$ & $\begin{array}{c}-0.59^{*} \\
(0.34)\end{array}$ & $\begin{array}{c}1.21^{*} \\
(0.53)\end{array}$ \\
\hline Rice & 0.033 & $\begin{array}{c}0.105 \\
(0.75)\end{array}$ & $\begin{array}{c}0.14 \\
(0.13)\end{array}$ & $\begin{array}{c}-0.21 \\
(0.25)\end{array}$ & $\begin{array}{c}-0.12^{* *} \\
(0.09)\end{array}$ & $\begin{array}{c}0.35^{*} \\
(0.16)\end{array}$ & $\begin{array}{c}0.03 \\
(0.62)\end{array}$ & $\begin{array}{c}0.18^{* *} \\
(0.114)\end{array}$ & $\begin{array}{c}0.01 \\
(0.02)\end{array}$ & $\begin{array}{c}0.28 \\
(0.65)\end{array}$ & $\begin{array}{l}-0.76 \\
(0.999)\end{array}$ \\
\hline Gram (Split) & 0.027 & $\begin{array}{c}-0.78^{* *} \\
(0.56)\end{array}$ & $\begin{array}{l}0.09 \\
(0.098)\end{array}$ & $\begin{array}{c}0.28^{* *} \\
(0.198)\end{array}$ & $\begin{array}{c}0.16^{*} \\
(0.07)\end{array}$ & $\begin{array}{l}-0.07 \\
(0.12)\end{array}$ & $\begin{array}{c}0.58^{* *} \\
(0.36)\end{array}$ & $\begin{array}{l}-0.12 \\
(0.124)\end{array}$ & $\begin{array}{l}-0.01 \\
(0.013)\end{array}$ & $\begin{array}{l}0.36 \\
(0.504)\end{array}$ & $\begin{array}{c}-0.49 \\
(0.79)\end{array}$ \\
\hline Mung (Split) & 0.001 & $\begin{array}{c}0.036 \\
(0.48)\end{array}$ & $\begin{array}{c}0.23 \\
(0.28)\end{array}$ & $\begin{array}{c}-0.23 \\
(0.53)\end{array}$ & $\begin{array}{l}0.55^{* *} \\
(0.34)\end{array}$ & $\begin{array}{c}0.93^{*} \\
(0.44)\end{array}$ & $\begin{array}{c}0.30 \\
(0.42)\end{array}$ & $\begin{array}{c}-0.12 \\
(0.11)\end{array}$ & $\begin{array}{c}-0.23^{*} \\
(0.12)\end{array}$ & $\begin{array}{c}-0.42 \\
(0.57)\end{array}$ & $\begin{array}{c}-1.06^{* *} \\
(0.78)\end{array}$ \\
\hline Milk (Fresh) & 0.196 & $\begin{array}{c}0.52 * \\
(0.18)\end{array}$ & $\begin{array}{c}-0.03 \\
(0.03)\end{array}$ & $\begin{array}{l}-0.06 \\
(0.059)\end{array}$ & $\begin{array}{c}-0.05^{*} \\
(0.016)\end{array}$ & $\begin{array}{l}-0.06 * \\
(0.03)\end{array}$ & $\begin{array}{c}0.02 \\
(0.09)\end{array}$ & $\begin{array}{c}0.002 \\
(0.02)\end{array}$ & $\begin{array}{c}-0.003 \\
(0.003)\end{array}$ & $\begin{array}{c}-0.39 * \\
(0.187)\end{array}$ & $\begin{array}{c}0.22 * \\
(0.11)\end{array}$ \\
\hline Others & 0.599 & $\begin{array}{l}1.34 * \\
(0.127)\end{array}$ & $\begin{array}{c}-0.02 \\
(0.01)\end{array}$ & $\begin{array}{c}0.008 \\
(0.03)\end{array}$ & $\begin{array}{c}0.008 \\
(0.007)\end{array}$ & $\begin{array}{c}0.01 \\
(0.02)\end{array}$ & $\begin{array}{l}-0.06^{* *} \\
(0.04)\end{array}$ & $\begin{array}{c}-0.02 * \\
(0.009)\end{array}$ & $\begin{array}{c}-0.003 * \\
(0.001)\end{array}$ & $\begin{array}{c}-0.14 \\
(0.08)\end{array}$ & $\begin{array}{l}1.07 * \\
(0.199)\end{array}$ \\
\hline
\end{tabular}

ote: Asymptotic standard errors are reported in parentheses.

* Indicates significance at 0.05 percent level.

** Indicate significance at 0.10 percent level. 
beef and mutton are also high in magnitude as expected. In contrast, the expenditure elasticity for gram (split) is negative, which shows its inferior nature as compared with meats. This is also plausible since gram is a cheaper substitute for meat for lowerincome households in Pakistan. Expenditure elasticity for mung (split) is not significantly different from zero.

A comparison with previous studies is not easy to make due to their disaggregation by urban and rural areas and the composite commodities taken. However, a remote comparison can be made with Alderman (1988), who used the LA/AIDS model. Elasticities from cross-section data "refer to long-run responses after several years of adjustment to new income or price levels"[Timmer and Alderman (1979)]. Therefore, the magnitude of elasticities from cross-section data are expected to be smaller than time series data. Likewise, the magnitude of our elasticities is relatively smaller than Alderman's (1988), who used the HIES data. For example, he found that the own-price compensated elasticity for meat in urban areas was -1.06 , while the elasticity for pulses (including gram and mung, etc.) was -0.39 . The magnitude of both elasticities is higher than ours. He also found that the own-price elasticity of dairy products is -2.84 , and 1.78 in rural and urban areas, respectively, which is much higher than our elasticity of 0.39 . Nonetheless, the signs of most of our comparable elasticities are similar as found by Alderman. At another level, composite commodities (e.g., meats, pulses, and dairy, etc.) are expected to be less price-elastic than disaggregated commodities (e.g., beef, mutton, chicken, and fish in the meat group) because disaggregated commodities have more available substitutes. On the contrary, the higher magnitude of Alderman's elasticities for composite commodities is surprising. Moreover, it is important to realise that the consequence of treating composite grouping as homogeneous commodities, in effect, means that all commodities in one group have the same price and income elasticities, which is misleading.

At another level, Behrman et al. (1997) suggest that understanding the consumption patterns for cultivating households requires a distinction on the basis of the stages of production because the planting stage consumption affects the harvest stage income through changes in current labour productivity. In particular, based on the longitudinal data from rural Pakistan, they find "small productivity effects of calorie consumption on the planting stage that are realised only in the harvest stage" for very poor households owning less than 1.5 acres of land. In other words, consumption decisions may not be separable from income at least for the poorest cultivating households. Therefore, if income causes consumption, and consumption in turn leads to changes in income, then there is a case for reverse causality or "feedback". If this "feedback" is strong, then both consumption and income should be viewed as endogenous in the estimated consumer demand models. However, our results presented above are not expected to be influenced by such effects. This is because only about 15 percent of Pakistani farmers cultivate less than 1.5 acres of land [Government of Pakistan (1997)]. Moreover, since we use aggregate time series data, which includes 
both urban and rural households, the incidence of small "feedback" effect, if any, on the poorest cultivating households would produce no or very little overall effects.

\section{CONCLUSIONS AND POLICY IMPLICATIONS}

This paper uses annual disappearance data of Pakistan from 1972-73 to 1991-92 to estimate consumer preferences for eight food commodities. The evidence in this paper supports the idea that only changes in relative prices and expenditures do not fully explain the observed food consumption patterns in Pakistan. The existence and the nature of structural change in consumer preferences is tested by using both GARP and the first-difference LA/AIDS model.

The GARP tests do not provide unequivocal support for change in consumer preferences due to a strong trend in expenditures, which reduces the power of these tests. Our attempts to adjust data for income growth by using expenditure elasticities suggested by Chalfant and Alston (1988) failed to "rationalise" the data. We interpret this as evidence of structural change in consumer preferences. Even though tests for structural change with the LA/AIDS model do support a shift towards chicken and away from gram after 1982-83, the roots of this shift are not identified by this study. It appears, however, that the movement towards chicken cannot be explained by the dietary concerns (preference for white meat) since the cross-price effects between red and white meats are not consistent with this view.

Government, in Pakistan, makes a number of decisions about the supply of essential food items and often intervenes in the market to regulate the prices of such items. Production targets are often set to private farmers and incentive packages are announced to meet these targets. Estimates of consumer demand elasticities are very important in making policy decisions on taxes, fixing prices, and in giving incentives to producers and consumers. Even though the interests of producers and consumers clash over pricing issues, problems of this nature can be resolved by knowledge about the elasticities of demand. More specifically, policy-makers can make use of own-price elasticities to predict the effects of the imposition of a tax or an increase in price by sellers on consumer demand. Consistent with earlier studies, we find that consumer demand for included commodities is quite inelastic. ${ }^{25}$ This inelastic pattern of demand suggests that sellers of these commodities have strong incentives to raise prices because doing so will ensure more revenues. Further, government can also generate more revenues by levying taxes on commodities with inelastic demand. However, policies in this direction should also rely on welfare considerations by keeping in mind the interests of both producers and consumers. The secondary effects of such policy changes are

\footnotetext{
${ }^{25}$ Among the included commodities, the highest magnitude for own-price elasticity is found for beef, where a 10 percent increase in the price of beef reduces beef demand by 5.8 percent, holding income and other prices constant. The demand for other included commodities is even more inelastic.
} 
predicted by estimates of cross-elasticities of demand. For instance, our results show that if a tax is imposed on beef, people will substitute out of beef into something that they consider a good substitute such as mutton or chicken. ${ }^{26}$

Estimates of expenditure elasticites are particularly relevant for producers and policy-makers to make investment decisions. Our estimates show that the demand for chicken is income-elastic, which implies that, other things being constant, as incomes increase, the use of chicken meat will increase rapidly, and vice versa. The negative sign for expenditure elasticity of gram (split) depicts that gram is an inferior good. In view of the recent wave of rising prices for consumer goods, the purchasing power of an average family in Pakistan has seriously been eroded, which may cause more gram to be purchased. In this scenario, if the government wants to target poor people, incentives to producers of gram may be a desirable policy option.

Previous studies have mostly estimated elasticities on commodity aggregates (meaning all commodities in a group have same price and income elasticities), which conceal important information that may be useful for policy. In future research, estimates of price and income elasticities on disaggregated commodities, instead of aggregated food groups, can provide additional insights to improve the functioning of these markets.

\footnotetext{
${ }^{26}$ This is indicated by significantly positive cross-price relation of beef with mutton and chicken.
} 
Appendices

Appendix Table 1

Data on Disappearances and Other Variables Used in Estimation (1980-81=100)

\begin{tabular}{|c|c|c|c|c|c|c|c|c|c|c|c|c|}
\hline \multirow[b]{2}{*}{ Year } & \multirow[b]{2}{*}{$\begin{array}{c}\text { Population } \\
\text { (Million) }\end{array}$} & \multirow{2}{*}{\multicolumn{2}{|c|}{$\begin{array}{l}\text { Total Personal } \\
\text { Consumption } \\
\text { Expenditure } \\
\text { (Rs Billion) } \\
\end{array}$}} & \multirow[b]{2}{*}{$\begin{array}{c}\text { Implicit Price } \\
\text { Deflator } \\
\text { (Index) }\end{array}$} & \multicolumn{8}{|c|}{ Per Capita Consumption of } \\
\hline & & & & & $\begin{array}{l}\text { Beef } \\
\text { (k.g.) }\end{array}$ & $\begin{array}{c}\text { Mutton } \\
\text { (k.g.) }\end{array}$ & $\begin{array}{c}\text { Chicken } \\
\text { (k.g.) }\end{array}$ & $\begin{array}{l}\text { Fish } \\
\text { (k.g.) }\end{array}$ & $\begin{array}{c}\text { Rice } \\
\text { (k.g.) }\end{array}$ & $\begin{array}{c}\text { Gram } \\
\text { (Split) } \\
\text { (k.g.) }\end{array}$ & $\begin{array}{l}\text { Mung } \\
\text { (Split) } \\
\text { (k.g.) }\end{array}$ & $\begin{array}{l}\text { Milk } \\
\text { (Fresh) } \\
\text { (k.g.) }\end{array}$ \\
\hline 1 & 2 & 3 & 4 & 5 & 6 & 7 & 8 & 9 & 10 & 11 & 12 & 13 \\
\hline $1972-73$ & 65.31 & 34.02 & 149.97 & 37.80 & 5.43 & 3.48 & 0.30 & 2.66 & 23.97 & 8.60 & 0.47 & 122.89 \\
\hline 1973-74 & 66.88 & 44.22 & 157.72 & 46.83 & 5.38 & 3.72 & 0.36 & 3.00 & 28.23 & 9.27 & 0.48 & 122.20 \\
\hline 1974-75 & 68.92 & 56.04 & 165.84 & 57.27 & 5.26 & 3.91 & 0.40 & 2.30 & 27.82 & 8.11 & 0.42 & 120.48 \\
\hline $1975-76$ & 71.03 & 62.57 & 174.39 & 64.17 & 5.18 & 4.12 & 0.49 & 2.33 & 26.53 & 8.60 & 0.46 & 119.41 \\
\hline 1976-77 & 73.21 & 69.94 & 183.37 & 71.01 & 5.20 & 4.21 & 0.51 & 2.73 & 25.73 & 9.01 & 0.41 & 118.31 \\
\hline 1977-78 & 75.44 & 75.39 & 192.82 & 77.41 & 5.24 & 4.30 & 0.55 & 3.43 & 28.91 & 8.27 & 0.41 & 117.22 \\
\hline 1978-79 & 77.75 & 80.39 & 202.76 & 81.67 & 5.28 & 4.38 & 0.57 & 3.65 & 29.57 & 7.03 & 0.39 & 116.14 \\
\hline $1979-80$ & 80.13 & 88.99 & 213.15 & 90.24 & 5.30 & 4.46 & 0.62 & 3.64 & 27.12 & 3.97 & 0.41 & 115.07 \\
\hline 1980-81 & 82.58 & 100.00 & 224.14 & 100.00 & 5.34 & 4.55 & 0.64 & 2.83 & 24.34 & 4.15 & 0.39 & 114.02 \\
\hline 1981-82 & 84.25 & 111.10 & 234.24 & 109.34 & 5.40 & 4.69 & 0.69 & 3.62 & 29.89 & 3.30 & 0.38 & 114.10 \\
\hline 1982-83 & 87.76 & 116.29 & 243.70 & 115.00 & 5.37 & 4.72 & 0.87 & 3.72 & 29.41 & 5.68 & 0.46 & 111.86 \\
\hline
\end{tabular}




\begin{tabular}{|c|c|c|c|c|c|c|c|c|c|c|c|c|}
\hline 1983-84 & 90.48 & 124.76 & 258.73 & 126.20 & 5.48 & 4.90 & 0.97 & 3.55 & 23.36 & 5.86 & 0.47 & 115.01 \\
\hline 1984-85 & 93.29 & 131.83 & 281.17 & 131.90 & 5.59 & 5.09 & 1.08 & 3.73 & 28.27 & 5.71 & 0.49 & 118.24 \\
\hline 1985-86 & 96.18 & 137.57 & 278.19 & 136.20 & 6.34 & 5.00 & 1.33 & 3.94 & 16.92 & 6.19 & 0.52 & 127.31 \\
\hline 1986-87 & 99.16 & 142.52 & 288.01 & 142.49 & 6.45 & 5.19 & 1.37 & 3.86 & 22.71 & 5.97 & 0.57 & 129.81 \\
\hline $1987-88$ & 102.24 & 151.49 & 317.35 & 156.20 & 6.57 & 5.39 & 1.53 & 3.82 & 20.18 & 3.70 & 0.43 & 132.36 \\
\hline 1988-89 & 105.41 & 167.23 & 319.91 & 169.60 & 6.69 & 5.60 & 1.66 & 3.87 & 22.66 & 4.40 & 0.40 & 134.97 \\
\hline 1989-90 & 108.68 & 177.33 & 334.31 & 180.30 & 6.82 & 5.81 & 1.47 & 3.76 & 23.15 & 5.25 & 0.53 & 137.64 \\
\hline 1990-91 & 112.05 & 199.78 & 329.87 & 199.70 & 6.94 & 6.03 & 1.37 & 3.93 & 18.64 & 4.81 & 0.51 & 140.38 \\
\hline 1991-92 & 115.52 & 218.99 & 375.70 & 219.50 & 7.06 & 6.27 & 1.37 & 3.93 & 15.22 & 4.51 & 0.45 & 143.18 \\
\hline
\end{tabular}

Notes: (1) All meats are sold fresh by retail meat shops at a uniform price for all subgroups of beef and mutton. Ground beef and ground mutton are also sold at the same price.

(2) Disaggregated data on wholesale chicken production by subgroups of broiler chicken and desi (local variety) chicken were not available. Therefore, data in column 8 shows consumption of composite chicken.

(3) Wholesale gram and mung production was multiplied by 0.98 to allow for the loss while converting gram and mung into gram (split) and mung (split) in columns 11 and 12.

(4) Large quantity of milk is consumed by sweet shops and other milk product producers. Therefore, to correct for retail consumption, wholesale milk production was multiplied by 0.85 to allow for these uses of milk.

(5) The data were extrapolated for missing data points. 
Appendix Table 2

Price Indices Used in Estimation (1980-81=100)

\begin{tabular}{|c|c|c|c|c|c|c|c|c|}
\hline Year & Beef & Mutton & Chicken & Fish & Rice & Gram (Split) & Mung (Split) & Milk (Fresh) \\
\hline 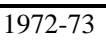 & 28.88 & 28.84 & 45.25 & 30.42 & 40.41 & 19.56 & 36.62 & 36.87 \\
\hline 1973-74 & 45.76 & 38.48 & 49.72 & 40.10 & 53.69 & 22.81 & 50.46 & 47.75 \\
\hline $1974-75$ & 60.87 & 51.56 & 67.08 & 52.08 & 54.28 & 28.30 & 51.69 & 63.66 \\
\hline $1975-76$ & 66.77 & 56.27 & 73.94 & 58.68 & 60.18 & 28.29 & 51.69 & 71.88 \\
\hline 1976-77 & 69.25 & 62.06 & 73.60 & 65.14 & 71.68 & 30.22 & 68.77 & 80.37 \\
\hline $1977-78$ & 70.50 & 68.04 & 71.48 & 70.52 & 83.19 & 45.93 & 84.92 & 82.49 \\
\hline 1978-79 & 76.71 & 75.33 & 79.07 & 73.74 & 88.20 & 39.85 & 85.69 & 85.41 \\
\hline 1979-80 & 83.33 & 82.07 & 92.08 & 85.58 & 85.84 & 41.93 & 84.46 & 92.31 \\
\hline 1980-81 & 100.00 & 100.00 & 100.00 & 100.00 & 100.00 & 100.00 & 100.00 & 100.00 \\
\hline 1981-82 & 112.11 & 109.10 & 110.83 & 111.91 & 126.84 & 140.74 & 146.77 & 111.40 \\
\hline 1982-83 & 118.74 & 112.54 & 118.69 & 128.55 & 134.51 & 127.26 & 133.54 & 123.10 \\
\hline 1983-84 & 127.33 & 122.18 & 122.94 & 145.98 & 134.22 & 97.48 & 149.38 & 131.30 \\
\hline 1984-85 & 135.51 & 131.46 & 126.95 & 156.96 & 138.64 & 97.48 & 145.69 & 146.70 \\
\hline $1985-86$ & 145.13 & 137.30 & 134.82 & 175.04 & 143.07 & 100.59 & 143.54 & 150.70 \\
\hline 1986-87 & 162.32 & 152.11 & 142.47 & 200.57 & 144.84 & 87.41 & 144.00 & 155.20 \\
\hline $1987-88$ & 179.92 & 171.71 & 153.91 & 217.93 & 150.15 & 107.26 & 162.92 & 161.30 \\
\hline 1988-89 & 216.98 & 195.79 & 179.07 & 237.95 & 159.88 & 177.48 & 226.31 & 171.60 \\
\hline 1989-90 & 240.58 & 216.16 & 179.52 & 248.78 & 168.44 & 144.15 & 191.38 & 189.40 \\
\hline 1990-91 & 264.08 & 228.11 & 197.77 & 289.42 & 179.94 & 116.30 & 194.46 & 204.50 \\
\hline 1991-92 & 306.63 & 243.82 & 200.27 & 326.39 & 205.60 & 128.89 & 248.62 & 234.00 \\
\hline
\end{tabular}

Notes: (1) All prices are averages of 12 centres.

(2) In 1980-81, the average prices wore:

beef=Rs 9.66/k.g.; mutton=Rs 22.09/k.g.; chicken=Rs 17.92/k.g.; fish=Rs 13.94/k.g.; rice=Rs 3.39/k.g.; gram=Rs 6.75/k.g.; mung=Rs 6.50/k.g.; and milk=Rs $4.44 /$ k.g.

(3) Data on retail prices of chicken were not available, therefore, we used wholesale prices of chicken.

(4) The data were extrapolated for missing data points. 


\section{REFERENCES}

Afriat, S. N. (1967) The Construction of a Utility Function from Expenditure Data. International Economic Review 8: 67-77.

Ahmad, E., and S. Ludlow (1987) Aggregate and Regional Demand Response Patterns in Pakistan. The Pakistan Development Review 26:4 645-655.

Ahmad, E., S. Ludlow, and Nicholas Stern (1988) Demand Response in Pakistan: A Modification of the Linear Expenditure System for 1976. The Pakistan Development Review 27:3 293-308.

Alderman, H. (1988) Estimates of Consumer Price Response in Pakistan using Market Prices as Data. The Pakistan Development Review 27:2 89-107.

Ali, M. Shaukat (1985) Household Consumption and Saving Behaviour in Pakistan: An Application of the Extended Linear Expenditure System. The Pakistan Development Review 24:1 23-37.

Alston, Julian M., and James A. Chalfant (1991) Can We Take the Con Out of Meat Demand Studies? Western Journal of Agricultural Economics 16: 36-48.

Alston, Julian M., and James A. Chalfant (1992) Consumer Demand Analysis according to GARP. Northeastern Journal of Agricultural and Resource Economics 21: 125139.

Alston, Julian M., and James A. Chalfant (1993) The Silence of the Lambdas: A Test of the Almost Ideal and Rotterdam Model. American Journal of Agricultural Economics 75: 304-313.

Barten, A. P. (1977) The System of Demand Functions Approach: A Review. Econometrica 45: 23-51.

Behrman, Jere R., Andrew D. Foster, and Mark R. Rosenzweig (1997) The Dynamics of Agricultural Production and the Calorie-Income Relationship: Evidence from Pakistan. Journal of Econometrics 77:1 187-207.

Bouis, Howarth E. (1992) Food Demand Elasticities by Income Group by Urban and Rural Population for Pakistan. The Pakistan Development Review 31:4 997-1017.

Brester, Gary W., and Michael K. Wohlgenant (1991) Estimating Interrelated Demands for Meats Using New Measures for Ground and Table Cut Beef. American Journal of Agricultural Economics 73:1182-94.

Brester, Gary W., and Michael K. Wohlgenant (1993) Correcting for Measurement Error in Food Demand Estimation. Review of Economics and Statistics 75: 352-356.

Burney, Nadeem A., and Ashfaque H. Khan (1991) Household Consumption Patterns in Pakistan: An Urban-rural Comparison using Micro Data. The Pakistan Development Review 30:2 145-171.

Chalfant, James A., and Julian M. Alston (1988) Accounting for Changes for Tastes. Journal of Political Economy 96: 391-410.

Chavas, J.-P., and T. L. Cox (1990) Non-parametric Demand Analysis: A Duality Approach. Department of Agricultural Economics, University of Wisconsin, 
Madison. (Staff Paper No. 265.)

Deaton, A. (1988) Quality, Quantity, and Spatial Variation of Price. American Economic Review 78:3 418-430.

Deaton, A., and J. Muellbauer (1980) An Almost Ideal Demand System. American Economic Review 70: 312-326.

Deaton, A., and J. Muellbauer (1980a) Economics and Consumer Behaviour. Cambridge: Cambridge University Press.

Eales, James S., and Laurian J. Unnevehr (1988) Demand for Beef and Chicken Products: Separability and Structural Change. American Journal of Agricultural Economics 70: 521-532.

Eales, James S., and Laurian J. Unnevehr (1993) Simultaneity and Structural Change in U.S. Meat Demand. American Journal of Agricultural Economics 75: 259-268.

Fleissig, Adrian R., A. Ronald Gallant, and John J. Seater (1995) Theory Matters: GARP, Separability, Aggregation, and Euler Equation Estimation. Seminar Series, Department of Economics, Kansas State University, July 22.

Green, R., and J. Alston (1990) Elasticities in AIDS Models. American Journal of Agricultural Economics 72: 442-445.

Green, R., and J. Alston (1991) Elasticities in AIDS Models: A Clarification and Extension. American Journal of Agricultural Economics 73: 874-875.

Hall, Bronwyn H. (1996) TSP Reference Manual Version 4.3. Palo Alto, CA: TSP International.

ILO/ARTEP (1987) Impact of Out and Return Migration on Domestic Employment in Pakistan. Bangkok: International Labour Organisation.

Irfan, M., and Rashid Amjad (1984) Poverty in Rural Pakistan. In E. Lee and A. R. Khan (eds) Poverty in Rural Asia. Bangkok: ILO/ARTEP.

Jensen, K., and S. Bevins (1991) The Demand for Butter, Margarine, and Oils: A Nonparametric Test for Evidence of Structural Change. Southern Journal of Agricultural Economics 23: 59-63.

Kazi, S. (1988) Domestic Impact of Remittances and Overseas Migration: Pakistan. New Delhi: ILO/UNDP (Project Working Paper No. 7.)

Kemal, A. R. (1981) Income Distribution in Pakistan: A Review. Pakistan Institute of Development Economics, Islamabad. (Mimeographed.)

King, Richard A. (1979) Choices and Consequences. American Journal of Agricultural Economics 61: 839-848.

King, Richard A. (1981) Choices and Consequences: Reply. American Journal of Agricultural Economics 63: 176-177.

Koo, A. Y. C. (1963) An Empirical Test of Revealed Preference Theory. Econometrica 31: 646-664.

Koo, A. Y. C. (1971) Revealed Preference: A Structural Analysis. Econometrica 31: 89-97. 
Lluch, C. (1973) The Extended Linear Expenditure System. European Economic Review 4: 21-32.

Mukhtar, Hanid (1985) Essays in Consumer Behaviour: Evidence from Pakistan Data. Ph.D. Thesis, Boston University. (Unpublished.)

Mukhtar, Hanid (1992) Comments (on "Food Demand Elasticities by Income Group by Urban and Rural Populations for Pakistan” by Howarth E. Bouis [1992]). The Pakistan Development Review 31:4 1016-1017.

Naqvi, S. N. H., and Peter A. Cornelisse (1986) Public Policy and Wheat Market in Pakistan. The Pakistan Development Review 25:2 99-126.

Pakistan, Government of (1991) Pakistan Statistical Yearbook 1991. Islamabad: Federal Bureau of Statistics, Statistics Division. (Also various other issues.)

Pakistan, Government of (1997) Economic Survey 1996-97. Islamabad: Economic Adviser's Wing, Finance Division. (Also various other issues.)

Stone, R. H. (1954) Linear Expenditure System and the Demand Analysis: An Application to the Pattern of British Demand. Economic Journal 64: 511-527.

Swofford, J. L., and G. A. Whitney (1987) Non-parametric Tests of Utility Maximisation and Weak Separability for Consumption, Leisure, and Money. Review of Economics and Statistics 69: 458-464.

Thurman, Walter N. (1987) The Poultry Market: Demand Stability and Industry Structure. American Journal of Agricultural Economics 69: 30-37.

Timmer, C. Peter, and H. Alderman (1979) Estimating Consumption Parameters for Food Policy Analysis. American Journal of Agricultural Economics ( Proceedings Issue). 61: 982-987.

Varian, Hal R. (1982) The Non-parametric Approach to Demand Analysis. Econometrica 50: 945-973.

Varian, Hal R. (1983) Non-parametric Tests of Consumer Behaviour. Review of Economic Studies 50: 99-110.

Varian, Hal R. (1992) Microeconomic Analysis. (3rd ed) New York: W. W. Norton and Company.

Wellman, Katharine F. (1992) The U.S. Retail Demand for Fish Products: An Application of the Almost Ideal Demand System. Applied Economics 24: 445-457. 